\title{
Spatial eco-evolutionary feedback in plant-pathogen interactions
}

\section{Tack, Ayco Jerome Michel}

2013

Tack , A J M \& Laine , A-L 2013 , ' Spatial eco-evolutionary feedback in plant-pathogen interactions ' , European Journal of Plant Pathology , vol. 138 , no. 3 , pp. 667-677 . https://doi.org/10.1007/s10658-0

http://hdl.handle.net/10138/43017

https://doi.org/10.1007/s10658-013-0353-x

acceptedVersion

Downloaded from Helda, University of Helsinki institutional repository.

This is an electronic reprint of the original article.

This reprint may differ from the original in pagination and typographic detail.

Please cite the original version. 
Running title: Spatial eco-evolutionary feedback

Title: Spatial eco-evolutionary feedback in plant-pathogen interactions

Ayco JM Tack and Anna-Liisa Laine*

Metapopulation Research Group, Department of Biosciences, University of Helsinki, PO Box 65

(Viikinkaari 1), Fl-00014 University of Helsinki, Finland

*Corresponding author; e-mail: anna-liisa.laine@helsinki.fi; phone: +358 9 19157750; fax: +358 9

19157694

Keywords: coevolution, eco-evolutionary dynamics, eco-evolutionary feedback, host-pathogen interactions, metapopulation, pathosystem 


\begin{abstract}
In recent years the potential for evolutionary change to drive ecological dynamics, and vice versa, has been widely recognized. However, the convincing examples of eco-evolutionary dynamics mainly stem from highly artificial experimental systems, with conspicuously few examples contributed by field systems. While rarely considered in the eco-evolutionary literature, the genefor-gene hypothesis inherently recognizes the tight link between evolutionary and ecological dynamics. The boom-and-bust dynamics of some agricultural pathogens are an extreme demonstration of this. In this perspective, we place plant-pathogen systems in a spatial ecoevolutionary framework, which recognizes that ecology and evolution are tightly linked, take place at the same time scale and are strongly influenced by spatial structure. Specifically, we i) exemplify how the ecological process of dispersal modifies rapid local coevolutionary dynamics and thereby shapes spatial variation in resistance, infectivity, and local adaptation; and ii) illustrate how the outcome of coevolution (spatial distribution in resistance, infectivity and local adaptation) drives ecological metapopulation processes. Overall, we conclude that both agricultural and wild pathosystems provide a unique illustration of the high relevance of spatial eco-evolutionary feedback in understanding species interactions.
\end{abstract}




\section{Eco-evolutionary dynamics}

The potential for eco-evolutionary feedback loops in determining the dynamics of populations has been increasingly recognized in recent years (Pelletier et al. 2009; Post and Palkovacs 2009; Schoener 2011; Ellner 2013; Reznick 2013). This feedback is comprised of two pathways: the ecology-to-evolution pathway, where ecological change generates genetic and phenotypic responses (natural selection); and the evolution-to-ecology pathway, where genetic and phenotypic change affects ecological quantities, often measured as the population growth rate. However, while the potential of species to adapt to ecological conditions has long been realized, the effect of rapid evolutionary change on ecological dynamics is still poorly understood. In part, this is due to the fact that traditionally evolution has been viewed as a slow process operating at a timescale that is very different from ecological time (Slobodkin 1961; Hutchinson 1965). From such a perspective, ecological dynamics would play out as if evolution was not occurring, as evolutionary change would be non-significant on the ecological time-scale. Likewise, short-term fluctuations in ecological variables would average out over evolutionary time-scales, and only the long-term average would affect evolution (Hairston et al. 2005). However, it is becoming increasingly clear that evolutionary change can be extremely rapid, and there are compelling examples of this in a diversity of traits ranging from life-histories to behaviour and physiology (as reviewed in Thompson 2013). Moreover, a rapidly increasing number of studies suggest that eco-evolutionary dynamics and feedbacks have the potential to play a prominent role in the dynamical behaviour of populations and species interactions (Schoener 2011; Farkas et al. 2013).

To date, the majority of eco-evolutionary studies have been conducted in highly artificial micro- or mesocosms (Pimentel 1968; Yoshida et al. 2003; Schoener 2011), or have applied treatments that may enforce much stronger selection pressures than may be encountered in natural systems (e.g. Agrawal et al. 2012). As another shortcoming, they have usually focused on a single facet of the eco-evolutionary feedback, addressing either the impact of ecology on rapid evolution (as reviewed in Thompson 2013) or evolution on ecology (Whitham et al. 2006; Bailey et al. 2009; Barbour et al. 2009; Harmon et al. 2009; Bassar et al. 2010; Busby et al. 2013). Many of the latter demonstrations are also 'retrospective' (Losos 1994), where researchers investigate the 
outcome of historical events on present day ecological processes. As such, these studies do not inform us on the temporal scale of ecological and evolutionary changes and their potential feedback. Hence, two recent reviews conclude that while mesocosm experiments and associated theory tell us that eco-evolutionary interactions may have potential importance, it remains unresolved whether such processes are important in nature or whether they are an artefact of highly simplified laboratory ecosystems (Schoener 2011; Reznick 2013).

While eco-evolutionary dynamics and feedback loops only recently emerged as a hotly debated and active field of research (Fussmann et al. 2007; Pelletier et al. 2009; Schoener 2011; Reznick 2013), plant pathologists have long realized that ecology and evolution are tightly interlinked, play out at the same time scale, and are ecologically relevant (Flor 1956; Antonovics 1992). Such early recognition of eco-evolutionary dynamics in host-pathogen interactions may have been fuelled by the early discovery of gene-for-gene interactions (Flor 1942), where evolutionary change even at a single locus (in either resistance or avirulence loci) can enable or prevent pathogen infection (Thompson and Burdon 1992). Nonetheless, insights gained from agricultural and wild plant pathosystems are not alluded to in recent reviews (e.g. Fussmann et al. 2007; Schoener 2011) or in special features on eco-evolutionary dynamics (Proceedings of the Royal Society B volume 366, 2009; American Naturalist volume 181, 2013). Here, we argue that the combined experimental and observational evidence from long-term studies in agricultural and wild pathosystems does not merely demonstrate the potential for eco-evolutionary feedback, but also settles the importance of eco-evolutionary feedbacks for our understanding of species interactions.

\section{A coevolutionary and spatial framework}

Studies on wild plant pathosystems have pioneered and excelled at exploring two research fields at the heart of ecology and evolution: coevolutionary interactions and ecological spatial dynamics. Both of these fields have thus far been largely ignored in the heated debate surrounding the relevance of eco-evolutionary dynamics. Therefore, it is here that plant pathology may provide novel insights into the mechanisms underlying eco-evolutionary feedback. 
Few co-evolutionary studies have been published under the header of eco-evolutionary dynamics (Jones et al. 2009; Toju 2011). However, an overwhelming number of studies illustrate that coevolutionary interactions among host and pathogens play a major role in explaining temporal and spatial variation in resistance, pathogenicity and local adaptation (Laine et al. 2011; Tack et al. 2012). While we note that coevolution per se does not imply a link between evolutionary and ecological timescales (as defined by e.g. Janzen (1980), coevolution refers to how two species evolve in response to each other, without regard to the time scale of evolutionary dynamics or the impact of evolutionary changes on ecological aspects like population dynamics), several recent studies have shown that plant-pathogen coevolution and local adaptation can be rapid (Capelle and Neema 2005; Laine 2005; Tack et al. 2012; Thrall et al. 2012) and may therefore impact on ecological processes.

While nothing (or little) makes sense in ecology and evolution without a spatial perspective (Hanski and Gaggiotti 2004), spatial complexity is rarely included in experimental studies. As a result, eco-evolutionary studies have focused on dynamics in single micro- and mesocosms (Pimentel 1968; Bohannan and Lenski 2000; Yoshida et al. 2003; Fussmann et al. 2007; Becks et al. 2010), small field plots (Agrawal et al. 2012) or single natural populations (Hairston et al. 2005; Grant and Grant 2006; Ezard et al. 2009). Hence, we lack general insights on how spatial dynamics affect eco-evolutionary feedbacks (but see Hanski 2011). In contrast, theoretical and empirical studies focusing on wild pathosystems have emphasized the ephemeral nature of local pathogen populations (Burdon 1987, 1993; Antonovics et al. 1994; Thrall and Burdon 1999; Burdon and Thrall 2013). To explain what happens in local populations, pathologists have expanded their scope and explored processes at the metapopulation scale like gene flow and extinction-colonization dynamics (Jarosz and Burdon 1991; Carlsson and Elmqvist 1992; Antonovics et al. 1994; Burdon et al. 1995; Ericson et al. 1999; Thrall et al. 2001; Petrželová and Lebeda 2004; Laine and Hanski 2006). In such spatially structured environments, we may expect local adaptation to emerge as a result of plant-pathogen coevolution (Kaltz and Shykoff 1998). Indicating a potential feedback loop, i) spatial patterns of resistance, infectivity and local adaptation may be affected by the spatial scale and magnitude of pathogen and host dispersal, and ii) spatial 
patterns of resistance, infectivity and local adaptation will affect the magnitude of gene flow and local demography (Gandon et al. 1996; Thrall and Burdon 1997, 1999; Gandon 2002; Gandon and Michalakis 2002; Lenormand 2002; Thrall and Burdon 2002; Thrall et al. 2002; Tack et al. 2013b). In an adapted landscape, spores colonizing new host populations will frequently be maladapted to the local host genotypes and environmental conditions in the new habitat patch, with major consequences for the settlement probability and ensuing local demography (Lenormand 2002). Hence, coevolutionary dynamics and ecological extinction-colonization dynamics may commonly influence each other and thereby lead to a coupling of ecological and evolutionary dynamics (cf. Hanski et al. 2011).

In this perspective, we illustrate how plant-pathogen interactions provide a unique opportunity for exploring eco-evolutionary feedback within a spatial framework (Fig. 1). We argue that accounting for the spatial context is critical for understanding how the eco-evolutionary feedback loops play out because of the natural patchy distribution of plants and pathogens. More specifically, we i) review how dispersal within the metapopulation affects local coevolutionary interactions, which ultimately shape the spatial and temporal distribution of plant resistance, pathogen infectivity and aggressiveness and local adaptation (arrow A in Fig. 1), and ii) quantify how spatial patterns in resistance, infectivity, aggressiveness and local adaptation may affect pathogen extinction-colonization dynamics and spatial spread (arrow B in Fig. 1).

\section{From ecology to evolution: spatial dynamics fuel coevolutionary dynamics}

There is large variation in the rate and scale of dispersal among crop pathogens, where some airborne rusts may exhibit intercontinental dispersal (Brown and Hovmøller 2002), whereas genetic neighbourhoods of other species, like soil-borne pathogens, may only encompass a section of a single field (Agrios 2005). Given such large differences in dispersal ability among species, we may use cross-species analyses to explore the consequences of gene flow for pathogen evolutionary potential. In a quantitative synthesis of 34 pathosystems, McDonald and Linde (2002) constructed a risk model including several key evolutionary forces (mutation rate, effective population size, gene flow and reproduction/mating system) to estimate the time to break down of newly deployed 
major resistance genes in crop plants. These analyses suggest that mutation rate and gene flow are the dominant forces driving pathogen evolution. The effect of gene flow may result from a larger effective population size and associated higher genetic diversity (McDonald and Linde 2002). Moreover, new mutations in pathogens with high gene flow, like rust and powdery mildew fungi, may rapidly spread across the landscape, whereas mutations in less dispersive pathogens, like the asexual phase of the wheat pathogens Mycosphaerella graminicola and Phaeosphaeria nodorum, may not spread beyond several tens of metres within the growing season (McDonald and Linde 2002). Additionally, new mutations in pathogens with limited dispersal have a higher likelihood to disappear due to environmental stochasticity.

In natural systems, theoretical host-pathogen models have demonstrated how critical gene flow among populations is for host-pathogen dynamics, local persistence and the maintenance of variation in host resistance and pathogenicity (Thrall and Antonovics 1995; Thrall and Burdon 1997, 1999, 2002; Brown and Tellier 2011; Tellier and Brown 2011). These predictions are backed up by the striking ephemerality of local pathogen populations, where the pathogen can only persist at the regional scale (Burdon and Thrall 2013). As many pathogens exhibit metapopulation dynamics, the encounter intensity among host and pathogen is spatially variable, ranging from strong pathogenmediated selection in some plant populations ('hotspots') to the absence of pathogens and pathogen-mediated selection pressures in other populations ('coldspots'), thereby creating geographic mosaic patterns of coevolution (Thompson 2005; Smith et al. 2011). The distribution of hotspots and coldspots within the metapopulation may not be random, but may depend on the spatial structure of the host populations: in general, pathogens may be most likely to colonize and persist in large populations (Carlsson and Elmqvist 1992; Burdon et al. 1995; Thrall and Antonovics 1995; Ericson et al. 1999; Carlsson-Granér and Thrall 2002; Laine and Hanski 2006; Smith et al. 2011). Asynchrony among populations in coevolutionary interactions, as based on limited dispersal, may further cause differentiation in the level of resistance and pathogenicity in local populations at a particular point in time (Kaltz and Shykoff 1998). Most importantly, the spatial variation in pathogen-mediated selection may result in the evolution of resistance genes in some populations, whereas costly resistance genes are lost in other populations due to trade-offs 
between plant resistance and other plant fitness components (Bergelson and Purrington 1996; Biere and Antonovics 1996; Tian et al. 2003; Giles et al. 2006). As a result, spatial variation in plant resistance may occur, which forms a blueprint for pathogen adaptation and plant-pathogen coevolution.

Dispersal plays a major role in driving plant-pathogen coevolution and patterns of local adaptation. Theoretical models have shown that the balance between pathogen and host dispersal influences whether the plant or pathogen may gain the upper hand in the coevolutionary race (Gandon et al. 1996; Gandon 2002; Gandon and Michalakis 2002). In many of the well-studied pathosystems pathogens are wind-dispersed and may gain an evolutionary advantage as compared to the plant. Indeed, the majority of studies find that pathogens are ahead in the coevolutionary race, likely due to a larger dispersal ability and reduced generation time (Kaltz and Shykoff 1998; Tack et al. 2012). However, counter-examples exist: the pollinator-dispersed anthersmut fungus Microbotryum violaceum is locally maladapted to its host plant Silene latifolia (Kaltz et al. 1999). Dispersal can also swamp local adaptation: Laine (2005) demonstrated the presence of local adaptation of the powdery mildew Podosphaera plantaginis, which frequently disperses up to 1 kilometre, to its host plant Plantago lanceolata at the scale of tens of kilometres, whereas no consistent pattern of local adaptation was detected at spatial scales ranging from a few hundred metres to several kilometres. A follow-up study showed that the spatial configuration of plant populations affected host-pathogen coevolution and patterns of local adaptation (Tack et al. 2013b). These studies illustrate that the spatial dynamics of plant and pathogen will affect the strength and sign of local adaptation. Overall, both agricultural and wild plant pathosystems provide evidence for a strong link between dispersal, local (co)evolutionary dynamics and patterns of local adaptation.

\section{From evolution to ecology: Coevolution shapes spatial dynamics}

The previous section exemplified how gene flow affects the level of host resistance, infectivity and local adaptation. Such variation in host resistance can be dramatic, with some plants being totally resistant whereas others are seemingly entirely susceptible (Burdon 1987). Given such spatial heterogeneity in host resistance and pathogen infectivity, strong genetic interaction between host 
and pathogen, and the resulting patterns of local adaptation, we may then expect that pathogen establishment is not randomly distributed in space. At the microscale, variation in resistance of individual plants within a single population may explain spore establishment; at the metapopulation scale, variation among populations in resistance may affect colonization rates and the magnitude of gene flow; and at the regional or continental scale patterns of resistance may affect invasion by new pathogen species or specific pathogen genotypes.

The agricultural literature provides a wealth of examples of how pathogen evolution, epidemiology and spatial spread are linked. In fact, the whole concept of resistance breeding is based on the underlying assumption of a direct evolution-to-ecology pathway, so that resistance will have a direct impact on pathogen epidemiology (Deadman 2006). Boom-and-bust cycles in pathogens arguably provide the most convincing and large body of evidence for natural selection in action, rapid evolution and its impact on spatial population dynamics. During the 'boom' phase, a resistant cultivar with a single major resistance gene is introduced into an agricultural system to reduce disease levels. When disease is significantly reduced and farmers are convinced of the agronomic value of the variety, the cultivar may soon be planted across a large area. However, the 'boom' phase is frequently followed by a 'bust' phase when an evolutionary change in the pathogen, like the loss of the elicitor recognized by the resistance gene, breaks down the resistance (McDonald and Linde 2002; Deadman 2006). Consequently, the virulent pathotypes rapidly spread and infect all fields with the 'resistant' cultivar. Half a decade ago, the development of resistant wheat varieties fuelled the Green Revolution, and scientists, breeders and farmers alike believed they had beaten the previously devastating stem rust Puccinia graminis for good. Hence, researchers and breeders were caught off-guard when the new strain Ug99, which can defeat the resistance of most of the world's wheat varieties, appeared in Uganda in 1999 (Pretorius et al. 2000; Stokstad 2007). In 2005, one of the Green Revolution pioneers Norman Borlaug sounded the alarm and urged for action (CIMMYT 2005), which resulted in a global research initiative to address the serious threat for world food security. Ug99 has since spread into South Africa, Yemen and Iran and threatens wheat crops throughout the Middle East and West Asia (Singh et al. 2011; http://wheatrust.cornell.edu). In 2000, canola (Brassica napa) cultivars with major resistance genes 
derived from Brassica rapa ssp. sylvestris against blackleg disease (Leptosphaeria maculans) were commercially released and grown extensively in some areas of Australia. Within three years from commercial release, resistance was rendered ineffective due to a large increase in the frequency of virulence alleles in the pathogen populations, which resulted in up to $90 \%$ yield losses and 5-10 million AUD damage in the Lower Eyre Peninsula, South Australia (Sprague et al. 2006; Van de Wouw et al. 2010a; Van de Wouw et al. 2010b). These boom-and-bust cycles illustrate the ubiquitous nature of rapid evolution in crop pathogens, and the profound consequences that such evolutionary change can have on disease epidemiology in agriculture (McDonald and Linde 2002).

Wild plant pathogens are patchily distributed across the landscape, with variation in disease incidence between plants, between populations, and across larger regions and continents (Burdon 1987, 1993). Such spatial distributions may be attributed to spatial variation in plant resistance, which is present at each of these spatial scales (Laine et al. 2011). At a small spatial scale, Tack et al (2013a) recently demonstrated that plant resistance and the spatial structure of plant genotypes have a major impact on disease spread in the powdery mildew Podosphaera plantaginis on its plantain host. At a larger spatial scale, variation across the plant metapopulation in the level of plant resistance may strongly affect the likelihood of successful colonization of non-infected plant populations (Thrall and Antonovics 1995; Carlsson-Granér 1997; Laine 2004). Using an elegant combination of computer simulations and empirical studies, Thrall \& Antonovics (1995) showed that high population turnover, low resistance costs and rapid loss of the pathogen with increasing host resistance results in higher plant resistance in healthy populations. Likewise, Laine (2004) showed that healthy plant populations of Plantago lanceolata had a two-fold higher resistance than pathogen-infected plant populations against four powdery mildew strains, suggesting that high resistance levels may prevent colonization by the pathogen. At the (inter)continental scale, longdistance pathogen dispersal and hosts jumps may result in rapid disease spread on the noncoevolved plant populations or plant species (Desprez-Loustau et al. 2007). A classic example is the accidental introduction in 1904 of the pathogen Cryphonectria parasitica from Japan, which rapidly spread throughout the American chestnut tree (Castanea dentata) populations resulting in 
the destruction of the dominant canopy tree throughout the Appalachian forests (Anagnostakis 1987).

While relatively few studies have compared healthy and diseased populations, a larger number of studies have focused on variation in plant resistance and pathogen infectivity among diseased populations. Here, reciprocal replant-transplant experiments and reciprocal inoculation studies have explored spatial variation in resistance and pathogenicity, frequently with the ultimate aim to demonstrate local adaptation of the plant or pathogen. Local adaptation turns out to be relatively common (roughly half of the studies) and is detected across spatial scales ranging from single plant individuals to metapopulations and continents (Kaltz and Shykoff 1998; Tack et al. 2012). Moreover, variation in plant resistance and infectivity is also common in study systems where no local adaptation is detected (Laine et al. 2011; Tack et al. 2012). Such spatial patterns of resistance, infectivity and local adaptation may directly impact on the level of gene flow across the landscape. First, when the average level of resistance varies across the landscape, we may expect non-random establishment success. For example, Springer (2007) detected a latitudinal cline in resistance structure of the California dwarf flax (Hesperolinon californicum), which mirrored almost identically a cline in infection prevalence detected in field surveys across the same biogeographic range. Such clines may create not only highly asymmetrical patterns of dispersal (from low resistance populations to high resistance populations), but variation in resistance would also affect parasite establishment. Notably, asymmetry in dispersal would itself have important consequences for further host-parasite coevolution (Vogwill et al. 2010; Gibert et al. 2013). While the example by Springer involved a resistance cline, non-clinal spatial variation in plant resistance will also create predictable variation in spore establishment and colonization. Second, patterns of local adaptation, represented by a match between resistance and pathogenicity, have the potential to change gene flow across the landscape. A recent synthesis by Laine and colleagues (2011) may allow for a tentative quantification of how local adaptation affects spore establishment or colonization success after spore dispersal. This cross-study comparison showed that pathogens are, on average, able to infect $68 \%$ of the local plant genotypes (i.e. present within the same population). However, the number of successful infections dramatically decreases with distance, where pathogens infect $61 \%$ 
of the plant genotypes located at distances ranging from a few hundred metres to several kilometres, and only $53 \%$ of plant genotypes collected from several kilometres up to several hundreds of kilometres. As a result, we may conclude that patterns of adaptation alone can explain 7 to $15 \%$ of the ecological variation in colonization success between plants located at a range of distances from the focal pathogen individual. Such patterns of local adaptation would effectively reduce the success of both intermediate and long-distance dispersal. Moreover, the decreased settlement success with increasing dispersal distance will also modify the shape of the effective dispersal kernel.

Pathogens may also adapt to plants growing in a particular ecotype. For example, the wild flax Melampsora lini shows strong local adaptation to plant genotypes collected from the same ecotype (Carlsson-Granér et al. 1999; Laine et al., in preparation). Reciprocal inoculation experiments demonstrate that ecotypic adaptation is very strong even across small spatial scales (several hundred metres); moreover, small-scale ecotypic adaptation is much stronger than adaptation among spatially widely spread populations (tens of kilometres) of the same ecotype (Laine et al., in preparation). In such cases, pathogen colonization and the fraction of spores that establish after immigration will be lower for plant populations that are surrounded by plant populations from a distinct ecotype. While the majority of local adaptation studies have focused on the metapopulation scale, similarly strong patterns of local adaptation within populations may explain the spatial distribution of pathogens within populations. A study by Capelle \& Neema (2005) indicates strong adaptation of Colletotrichum lindemuthianum to individual bean plants Phaseolus vulgaris separated by only a few metres. At a slightly larger spatial scale, Roslin et al (2007) detected local adaptation of oak mildew to individual oak trees distributed across a $5 \mathrm{~km}^{2}$ island. The latter study suggests that gene flow and colonization within the oak stand is reduced by an average of $7 \%$ due to patterns of pathogen local adaptation to single tree individuals.

While we here discussed the impact of evolution on patterns of spatial spread, we recognize that extinction, which underlies metapopulation dynamics, may likewise be strongly affected by evolution. Indeed, pathogen extinction may be affected by inbreeding or the lack of evolutionary potential (themselves strongly affected by gene flow). A combination of modelling and 
empirical data on multi-year changes in the numbers of healthy and anther-smut infected white campion (Silene latifolia) individuals in experimental field plots suggested that the disease would eventually be purged from resistant plant populations while host-pathogen coexistence was likely in susceptible plant populations (Thrall and Jarosz 1994). Susi and Laine (2013) found that newly established populations of Podosphaera plantaginis were more likely to go extinct than older pathogen populations, suggesting that adaptation plays a role in pathogen extinction. Finally, one common mechanism may involve the smaller pathogen population size in more resistant plant populations, which would significantly reduce the likelihood of pathogen survival during the highly stochastic overwintering season.

\section{Closing the loop: eco-evolutionary feedback}

Hairston and colleagues (2005) defined rapid evolution as a genetic change occurring rapidly enough to have a measurable impact on simultaneous ecological change. In such a scenario, a feedback loop between ecology and evolution may drive spatial dynamics. In agriculture, a humanmediated eco-evolutionary feedback loop, described above as the boom-and-bust cycle, has been ongoing for many crop-pathogen systems (McDonald and Linde 2002). Since the discovery of Mendelian inheritance of major resistance genes by Biffen over a century ago (1905), these cycles may have increased in spatial scale and amplitude due to increased plant breeding techniques and genetic modifications speeding up plant adaptation to the contemporary pathogen population; at the same time, increased gene flow and monocultures may increase the rate of pathogen evolution and the breakdown of plant resistance. Notably, major investments may be aimed at breaking or slowing down the eco-evolutionary feedback loop in agriculture. A classic example is the battle against wheat stem rust in the northern USA. With one of the aims to decrease the evolutionary potential of the pathogen, a massive public campaign led to the eradication of over 500 million barberry bushes (which are the site of sexual reproduction for the rust pathogen). As a result, the evolutionary potential of the wheat stem rust has decreased (as reflected in the lower pathogen diversity and increased temporal stability of the dominant pathogen races) and the ecoevolutionary feedback loop has significantly slowed down (Roelfs 1982; Peterson et al. 2005). 
Other attempts to slow down pathogen evolution, and therefore the need to develop cultivars with new major resistance genes, consist of the optimal deployment of multilines and cultivar mixtures (Wolfe 1985; Mundt 2002) and crop rotation. While large-scale boom-and-bust cycles may be contingent on the widespread deployment of major resistance genes in modern agriculture characterized by monoculture and genetic uniformity (McDonald and Linde 2002), there is emerging evidence of ongoing coevolution between resistance and avirulence genes since the dawn of agriculture. For example, new resistance genes effective against powdery mildew have been rapidly generated after wheat domestication (Yahiaoui et al. 2006). These new resistance genes may explain the proliferation since domestication of large numbers of avirulence genes in parasite genomes like the powdery mildew Blumeria graminis, where subsequent mutation of these genes would allow new isolates to escape recognition by these new resistance genes (Sacristán et al. 2009).

For wild plant-pathogen systems, we reviewed a large number of studies that demonstrate the ecology-to-evolution and evolution-to-ecology pathways. The ubiquitous nature of local adaptation and ecological extinction-colonization dynamics in plant pathogen interactions, and the reciprocity between local adaptation and ecological extinction-colonization dynamics, provide a strong argument that eco-evolutionary feedback loops will be a common and relevant force in plant-pathogen interactions. Notably, such eco-evolutionary dynamics do not generally have to result in directional evolutionary changes; however, interactions between spatial ecology and coevolution within metapopulations may play a crucial role in maintaining genetic and phenotypic variation due to fluctuating selection in space and time (cf. Hanski 2012). Given the presence of several long-term and detailed surveys on pathogen population dynamics in wild plant populations, and the rapid advance of molecular techniques to analyse genetic changes (e.g. Thrall et al. 2012), a promising approach to further investigate eco-evolutionary feedback loops may be to explore the interface between eco-evolutionary models and epidemiological data (cf. Luo and Koelle 2013). Fascinatingly, plant pathosystems have a long history of such data-driven eco-evolutionary modelling. In the early nineties, an eco-evolutionary model incorporating variation in host resistance of the white campion Silene latifolia could explain the empirical data on local population 
trajectories (coexistence, extinction) in experimental plots of the plant and its anther-smut pathogen (Thrall and Jarosz 1994). A follow-up model instigated by the empirical observation of frequent local population extinctions and colonizations explored how among-patch movement could explain variation in resistance and infectivity at the metapopulation scale (Thrall and Antonovics 1995). Similar simulations at an even larger spatial scale in a related pathosystem (the anther-smut Microbotryum violaceum on the host plant Lychnis alpina) revealed that ecoevolutionary models well fitted the empirical pattern of higher incidence but lower prevalence of the pathogen in relatively continuous plant metapopulations as compared to more fragmented landscapes (Carlsson-Granér and Thrall 2002). In contrast, ecological models assuming that the plant is uniformly susceptible failed to explain the empirical pattern (Carlsson-Granér and Thrall 2002). While the anther-smut fungus may lack genetic diversity in some regions, the widespread variation in infectivity and aggressiveness in the majority of plant pathogens (Tack et al. 2012) will necessitate the incorporation of coevolutionary dynamics within future spatially explicit ecoevolutionary models.

Overall, our perspective illustrates that plant-pathogen systems provide unique insights into the role of coevolution and spatial dynamics in driving ecologically relevant eco-evolutionary feedback loops. Given the detailed and long-term studies available, pathologists are in an excellent position to further advance the study of eco-evolutionary feedbacks in wild systems. From an applied perspective, an increased understanding of eco-evolutionary dynamics may, as envisioned by Pimentel 45 years ago (1968; see also Luo \& Koelle, 2013), be crucial for improvement of integrated control strategies.

\section{Acknowledgments}

This work was supported by funding from the Academy of Finland (Grant Nos 250444, 136393, 133499) and European Research Council (PATHEVOL; 281517) to ALL and a grant from the Academy of Finland to AT (Grant No 265761).

\section{References}


Agrawal, A. A., Hastings, A. P., Johnson, M. T. J., Maron, J. L., \& Salminen, J.-P. (2012). Insect herbivores drive real-time ecological and evolutionary change in plant populations. Science, $338,113-116$

Agrios, G. N. (2005). Plant pathology (5th ed.). New York, USA: Academic press.

Anagnostakis, S. L. (1987). Chestnut blight: the classical problem of an introduced pathogen. Mycologia, 79, 23-37.

Antonovics, J. (1992). Toward community genetics. In R. S. Fritz, \& E. L. Simms (Eds.), Plant resistance to herbivores and pathogens: ecology, evolution and genetics. (pp. 426-449). Chicago, USA: University of Chicago Press.

Antonovics, J., Thrall, P. H., Jarosz, A. M., \& Stratton, D. (1994). Ecological genetics of metapopulations: the Silene-Ustilago plant-pathogen system. In L. A. Real (Ed.), Ecological genetics (pp. 146-170). Princeton, New Jersey, USA: Princeton University Press

Bailey, J. K., Schweitzer, J. A., Úbeda, F., Koricheva, J., LeRoy, C. J., Madritch, M. D., et al. (2009). From genes to ecosystems: a synthesis of the effects of plant genetic factors across levels of organization. Philosophical Transactions of the Royal Society B: Biological Sciences, 364, 1607-1616.

Barbour, R. C., O'Reilly-Wapstra, J. M., De Little, D. W., Jordan, G. J., Steane, D. A., Humphreys, J. R., et al. (2009). A geographic mosaic of genetic variation within a foundation tree species and its community-level consequences. Ecology, 90, 1762-1772.

Bassar, R. D., Marshall, M. C., López-Sepulcre, A., Zandonà, E., Auer, S. K., Travis, J., et al. (2010). Local adaptation in Trinidadian guppies alters ecosystem processes. Proceedings of the National Academy of Sciences of the United States of America, 107, 3616-3621.

Becks, L., Ellner, S. P., Jones, L. E., \& Hairston Jr, N. G. (2010). Reduction of adaptive genetic diversity radically alters eco-evolutionary community dynamics. Ecology Letters, 13, 989997.

Bergelson, J., \& Purrington, C. B. (1996). Surveying patterns in the cost of resistance in plants. The American Naturalist, 148, 536-558. 
Biere, A., \& Antonovics, J. (1996). Sex-specific costs of resistance to the fungal pathogen Ustilago violacea (Microbotryum violaceum) in Silene alba. Evolution, 50, 1098-1110.

Biffen, R. H. (1905). Mendel's laws of inheritance and wheat breeding. The Journal of Agricultural Science, 1, 4-48.

Bohannan, B. J. M., \& Lenski, R. E. (2000). Linking genetic change to community evolution: insights from studies of bacteria and bacteriophage. Ecology Letters, 3, 362-377.

Brown, J. K. M., \& Hovmøller, M. S. (2002). Aerial dispersal of pathogens on the global and continental scales and its impact on plant disease. Science, 297, 537-541.

Brown, J. K. M., \& Tellier, A. (2011). Plant-parasite coevolution: bridging the gap between genetics and ecology. Annual Review of Phytopathology, 49, 345-367.

Burdon, J. J. (1987). Diseases and plant population biology. Cambridge, UK: Cambridge University Press.

Burdon, J. J. (1993). The structure of pathogen populations in natural plant communities. Annual Review of Phytopathology, 31, 305-323.

Burdon, J. J., Ericson, L., \& Müller, W. J. (1995). Temporal and spatial changes in a metapopulation of the rust pathogen Triphragmium ulmariae and its host, Filipendula ulmaria. Journal of Ecology, 83, 979-989.

Burdon, J. J., \& Thrall, P. H. (2013). What have we learned from studies of wild plant-pathogen associations?-the dynamic interplay of time, space and life-history. European Journal of Plant Pathology, 10.1007/s10658-10013-10265-10659.

Busby, P. E., Newcombe, G., Dirzo, R., \& Whitham, T. G. (2013). Genetic basis of pathogen community structure for foundation tree species in a common garden and in the wild. Journal of Ecology, 101, 867-877.

Capelle, J., \& Neema, C. (2005). Local adaptation and population structure at a micro-geographical scale of a fungal parasite on its host plant. Journal of Evolutionary Biology, 18, 1445-1454.

Carlsson-Granér, U. (1997). Anther-smut disease in Silene dioica: variation in susceptibility among genotypes and populations, and patterns of disease within populations. Evolution, 51, 1416-1426. 
Carlsson-Granér, U., Burdon, J. J., \& Thrall, P. H. (1999). Host resistance and pathogen virulence across a plant hybrid zone. Oecologia, 121, 339-347.

Carlsson-Granér, U., \& Thrall, P. H. (2002). The spatial distribution of plant populations, disease dynamics and evolution of resistance. Oikos, 97, 97-110.

Carlsson, U., \& Elmqvist, T. (1992). Epidemiology of anther-smut disease (Microbotryum violaceum) and numeric regulation of populations of Silene dioica. Oecologia, 90, 509-517. CIMMYT (2005). Sounding the alarm on global stem rust.

http://www.globalrust.org/traction/permalink/about37@1.

Deadman, M. L. (2006). Epidemiological consequences of plant disease resistance. In B. M. Cooke, D. Gareth Jones, \& B. Kaye (Eds.), The epidemiology of plant diseases (2nd ed., pp. 139-157). Dordrecht, the Netherlands: Springer.

Desprez-Loustau, M.-L., Robin, C., Buée, M., Courtecuisse, R., Garbaye, J., Suffert, F., et al. (2007). The fungal dimension of biological invasions. Trends in Ecology \& Evolution, 22, 472-480.

Ellner, S. P. (2013). Rapid evolution: from genes to communities, and back again? Functional Ecology, 27, 1087-1099.

Ericson, L., Burdon, J. J., \& Müller, W. J. (1999). Spatial and temporal dynamics of epidemics of the rust fungus Uromyces valerianae on populations of its host Valeriana salina. Journal of Ecology, 87, 649-658.

Ezard, T. H. G., Côté, S. D., \& Pelletier, F. (2009). Eco-evolutionary dynamics: disentangling phenotypic, environmental and population fluctuations. Philosophical Transactions of the Royal Society B: Biological Sciences, 364, 1491-1498.

Farkas, T. E., Mononen, T., Comeault, A. A., Hanski, I., \& Nosil, P. (2013). Evolution of camouflage drives rapid ecological change in an insect community. Current Biology, 23, 1835-1843.

Flor, H. H. (1942). Inheritance of pathogenicity in Melampsora lini. Phytopathology, 32, 653-669.

Flor, H. H. (1956). The complementary genic systems in flax and flax rust. Advances in Genetics, 8 , 29-54. 
Fussmann, G. F., Loreau, M., \& Abrams, P. A. (2007). Eco-evolutionary dynamics of communities and ecosystems. Functional Ecology, 21, 465-477.

Gandon, S. (2002). Local adaptation and the geometry of host-parasite coevolution. Ecology Letters, 5, 246-256.

Gandon, S., Capowiez, Y., Dubois, Y., Michalakis, Y., \& Olivieri, I. (1996). Local adaptation and gene-for-gene coevolution in a metapopulation model. Proceedings of the Royal Society B: Biological Sciences, 263, 1003-1009.

Gandon, S., \& Michalakis, Y. (2002). Local adaptation, evolutionary potential and host-parasite coevolution: interactions between migration, mutation, population size and generation time. Journal of Evolutionary Biology, 15, 451-462.

Gibert, J. P., Pires, M. M., Thompson, J. N., \& Guimarães, P. R. (2013). The spatial structure of antagonistic species affects coevolution in predictable ways. The American Naturalist, 182, $578-591$.

Giles, B. E., Pettersson, T. M., Carlsson-Granér, U., \& Ingvarsson, P. K. (2006). Natural selection on floral traits of female Silene dioica by a sexually transmitted disease. New Phytologist, 169, 729-739.

Grant, P. R., \& Grant, B. R. (2006). Evolution of character displacement in Darwin's finches. Science, 313, 224-226.

Hairston, N. G., Ellner, S. P., Geber, M. A., Yoshida, T., \& Fox, J. A. (2005). Rapid evolution and the convergence of ecological and evolutionary time. Ecology Letters, 8, 1114-1127.

Hanski, I. (2012). Eco-evolutionary dynamics in a changing world. Annals of the New York Academy of Sciences, 1249, 1-17.

Hanski, I., \& Gaggiotti, O. (2004). Ecology, genetics and evolution of metapopulations. Amsterdam: Elsevier Academic Press.

Hanski, I., Mononen, T., \& Ovaskainen, O. (2011). Eco-evolutionary metapopulation dynamics and the spatial scale of adaptation. The American Naturalist, 177, 29-43.

Hanski, I. A. (2011). Eco-evolutionary spatial dynamics in the Glanville fritillary butterfly. Proceedings of the National Academy of Sciences, 108, 14397-14404. 
Harmon, L. J., Matthews, B., Des Roches, S., Chase, J. M., Shurin, J. B., \& Schluter, D. (2009). Evolutionary diversification in stickleback affects ecosystem functioning. Nature, 458, 11671170.

Hutchinson, G. E. (1965). The ecological theater and the evolutionary play. New Haven, CT: Yale University Press.

Janzen, D. H. (1980). When is it coevolution. Evolution, 34, 611-612.

Jarosz, A. M., \& Burdon, J. J. (1991). Host-pathogen interactions in natural populations of Linum marginale and Melampsora lini: II. Local and regional variation in patterns of resistance and racial structure. Evolution, 45, 1618-1627.

Jones, Emily I., Ferrière, R., \& Bronstein, Judith L. (2009). Eco-evolutionary dynamics of mutualists and exploiters. The American Naturalist, 174, 780-794.

Kaltz, O., Gandon, S., Michalakis, Y., \& Shykoff, J. A. (1999). Local maladaptation in the anthersmut fungus Microbotryum violaceum to its host plant Silene latifolia: evidence from a cross-inoculation experiment. Evolution, 53, 395-407.

Kaltz, O., \& Shykoff, J. A. (1998). Local adaptation in host-parasite systems. Heredity, 81, 361-370.

Laine, A.-L. (2004). Resistance variation within and among host populations in a plant-pathogen metapopulation: implications for regional pathogen dynamics. Journal of Ecology, 92, 9901000.

Laine, A.-L. (2005). Spatial scale of local adaptation in a plant-pathogen metapopulation. Journal of Evolutionary Biology, 18, 930-938.

Laine, A.-L., Burdon, J. J., Dodds, P. N., \& Thrall, P. H. (2011). Spatial variation in disease resistance: from molecules to metapopulations. Journal of Ecology, 99, 96-112.

Laine, A.-L., \& Hanski, I. (2006). Large-scale spatial dynamics of a specialist plant pathogen in a fragmented landscape. Journal of Ecology, 94, 217-226.

Lenormand, T. (2002). Gene flow and the limits to natural selection. Trends in Ecology \& Evolution, 17, 183-189.

Losos, J. B. (1994). Integrative approaches to evolutionary ecology: Anolis lizards as model systems. Annual Review of Ecology and Systematics, 25, 467-493. 
Luo, S., \& Koelle, K. (2013). Navigating the devious course of evolution: the importance of mechanistic models for identifying eco-evolutionary dynamics in nature. The American Naturalist, 181, S58-S75.

McDonald, B. A., \& Linde, C. (2002). Pathogen population genetics, evolutionary potential, and durable resistance. Annual Review of Phytopathology, 40, 349-379.

Mundt, C. C. (2002). Use of multiline cultivars and cultivar mixtures for disease management. Annual Review of Phytopathology, 40, 381-410.

Pelletier, F., Garant, D., \& Hendry, A. P. (2009). Eco-evolutionary dynamics. Philosophical Transactions of the Royal Society B: Biological Sciences, 364, 1483-1489.

Peterson, P. D., Leonard, K. J., Roelfs, A. P., \& Sutton, T. B. (2005). Effect of barberry eradication on changes in populations of Puccinia graminis in Minnesota. Plant Disease, 89, 935-940.

Petrželová, I., \& Lebeda, A. (2004). Occurrence of Bremia lactucae in natural populations of Lactuca serriola. Journal of Phytopathology, 152, 391-398.

Pimentel, D. (1968). Population regulation and genetic feedback: evolution provides foundation for control of herbivore, parasite, and predator numbers in nature. Science, 159, 1432-1437.

Post, D. M., \& Palkovacs, E. P. (2009). Eco-evolutionary feedbacks in community and ecosystem ecology: interactions between the ecological theatre and the evolutionary play. Philosophical Transactions of the Royal Society B: Biological Sciences, 364, 1629-1640.

Pretorius, Z. A., Singh, R. P., Wagoire, W. W., \& Payne, T. S. (2000). Detection of virulence to wheat stem rust resistance gene Sr31 in Puccinia graminis f. sp. tritici in Uganda. Plant Disease, 84, 203.

Reznick, D. N. (2013). A critical look at reciprocity in ecology and evolution: introduction to the symposium. The American Naturalist, 181, S1-S8.

Roelfs, A. P. (1982). Effects of barberry eradication on stem rust in the United States. Plant Disease, 66, 177-181.

Roslin, T., Laine, A.-L., \& Gripenberg, S. (2007). Spatial population structure in an obligate plant pathogen colonizing oak Quercus robur. Functional Ecology, 21, 1168-1177. 
Sacristán, S., Vigouroux, M., Pedersen, C., Skamnioti, P., Thordal-Christensen, H., Micali, C., et al. (2009). Coevolution between a family of parasite virulence effectors and a class of LINE-1 retrotransposons. PLOS ONE, 4, e7463.

Schoener, T.W. (2011). The newest synthesis: understanding the interplay of evolutionary and ecological dynamics. Science, 331, 426-429.

Singh, R. P., Hodson, D. P., Huerta-Espino, J., Jin, Y., Bhavani, S., Njau, P., et al. (2011). The emergence of Ug99 races of the stem rust fungus is a threat to world wheat production. Annual Review of Phytopathology, 49, 465-481.

Slobodkin, L. B. (1961). Growth and regulation of animal populations. New York: Holt, Rinehart and Winston.

Smith, D. L., Ericson, L., \& Burdon, J. J. (2011). Co-evolutionary hot and cold spots of selective pressure move in space and time. Journal of Ecology, 99, 634-641.

Sprague, S. J., Balesdent, M.-H., Brun, H., Hayden, H. L., Marcroft, S. J., Pinochet, X., et al. (2006). Major gene resistance in Brassica napus (oilseed rape) is overcome by changes in virulence of populations of Leptosphaeria maculans in France and Australia. European Journal of Plant Pathology, 114, 33-40.

Springer, Y. P. (2007). Clinal resistance structure and pathogen local adaptation in a serpentine flax-flax rust interaction. Evolution, 61, 1812-1822.

Stokstad, E. (2007). Deadly wheat fungus threatens world's breadbaskets. Science, 315, 17861787.

Susi, H., \& Laine, A.-L. (2013). Pathogen life-history trade-offs revealed in allopatry. Evolution, 67, 3362-3370.

Tack, A. J. M., Hakala, J., Petäjä, T., Kulmala, M., \& Laine, A.-L. (2013a). Genotype and spatial structure shape pathogen dispersal and disease dynamics at small spatial scales. Ecology, 10.1890/1813-0518.1891.

Tack, A. J. M., Horns, F., \& Laine, A.-L. (2013b). The impact of spatial scale and habitat configuration on patterns of trait variation and local adaptation in a wild plant parasite. Evolution, doi:10.1111/evo.12239. 
Tack, A. J. M., Thrall, P. H., Barrett, L. G., Burdon, J. J., \& Laine, A.-L. (2012). Variation in infectivity and aggressiveness in space and time in wild host-pathogen systems: causes and consequences. Journal of Evolutionary Biology, 25, 1918-1936.

Tellier, A., \& Brown, J. K. M. (2011). Spatial heterogeneity, frequency-dependent selection and polymorphism in host-parasite interactions. BMC Evolutionary Biology, 11, 319.

Thompson, J. N. (2005). The geographic mosaic of coevolution. Chicago, USA: University of Chicago Press.

Thompson, J. N. (2013). Relentless evolution. Chicago, USA: University Of Chicago Press.

Thompson, J. N., \& Burdon, J. J. (1992). Gene-for-gene coevolution between plants and parasites. Nature, 360, 121-125.

Thrall, P. H., \& Antonovics, J. (1995). Theoretical and empirical studies of metapopulations: population and genetic dynamics of the Silene-Ustilago system. Canadian Journal of Botany, 73, S1249-S1258.

Thrall, P. H., \& Burdon, J. J. (1997). Host-pathogen dynamics in a metapopulation context: the ecological and evolutionary consequences of being spatial. Journal of Ecology, 85, 743-753.

Thrall, P. H., \& Burdon, J. J. (1999). The spatial scale of pathogen dispersal: consequences for disease dynamics and persistence. Evolutionary Ecology Research, 1, 681-701.

Thrall, P. H., \& Burdon, J. J. (2002). Evolution of gene-for-gene systems in metapopulations: the effect of spatial scale of host and pathogen dispersal. Plant Pathology, 51, 169-184.

Thrall, P. H., Burdon, J. J., \& Bever, J. D. (2002). Local adaptation in the Linum marginale Melampsora lini host-pathogen interaction. Evolution, 56, 1340-1351.

Thrall, P. H., Burdon, J. J., \& Bock, C. H. (2001). Short-term epidemic dynamics in the Cakile maritima-Alternaria brassicicola host-pathogen association. Journal of Ecology, 89, 723735.

Thrall, P. H., \& Jarosz, A. M. (1994). Host-pathogen dynamics in experimental populations of Silene alba and Ustilago violacea. II. Experimental tests of theoretical models. Journal of Ecology, 82, 561-570. 
Thrall, P. H., Laine, A.-L., Ravensdale, M., Nemri, A., Dodds, P. N., Barrett, L. G., et al. (2012). Rapid genetic change underpins antagonistic coevolution in a natural host-pathogen metapopulation. Ecology Letters, 15, 425-435.

Tian, D., Traw, M. B., Chen, J. Q., Kreitman, M., \& Bergelson, J. (2003). Fitness costs of R-genemediated resistance in Arabidopsis thaliana. Nature, 423, 74-77.

Toju, H. (2011). Weevils and camellias in a Darwin's race: model system for the study of ecoevolutionary interactions between species. Ecological Research, 26, 239-251.

Van de Wouw, A. P., Cozijnsen, A. J., Hane, J. K., Brunner, P. C., McDonald, B. A., Oliver, R. P., et al. (2010a). Evolution of linked avirulence effectors in Leptosphaeria maculans is affected by genomic environment and exposure to resistance genes in host plants. PLoS Pathogens, 6, e1001180.

Van de Wouw, A. P., Stonard, J. F., Howlett, B. J., West, J. S., Fitt, B. D. L., \& Atkins, S. D. (2010b). Determining frequencies of avirulent alleles in airborne Leptosphaeria maculans inoculum using quantitative PCR. Plant Pathology, 59, 809-818.

Vogwill, T., Fenton, A., \& Brockhurst, M. A. (2010). How does spatial dispersal network affect the evolution of parasite local adaptation? Evolution, 64, 1795-1801.

Whitham, T. G., Bailey, J. K., Schweitzer, J. A., Shuster, S. M., Bangert, R. K., Leroy, C. J., et al. (2006). A framework for community and ecosystem genetics: from genes to ecosystems. Nature Reviews Genetics, 7, 510-523.

Wolfe, M. S. (1985). The current status and prospects of multiline cultivars and variety mixtures for disease resistance. Annual Review of Phytopathology, 23, 251-273.

Yahiaoui, N., Brunner, S., \& Keller, B. (2006). Rapid generation of new powdery mildew resistance genes after wheat domestication. The Plant Journal, 47, 85-98.

Yoshida, T., Jones, L. E., Ellner, S. P., Fussmann, G. F., \& Hairston Jr, N. G. (2003). Rapid evolution drives ecological dynamics in a predator-prey system. Nature, 424, 303-306. 


\section{Figure legends}

Fig. 1 Schematic overview of the spatial eco-evolutionary feedback loop. Arrow A illustrates the impact of spatial ecology on local (co)evolution, where gene flow affects the level of plant resistance, pathogen infectivity and aggressiveness and local adaptation. In turn, the evolution of plant resistance, pathogen infectivity, pathogen aggressiveness and local adaptation may have a strong impact on the likelihood of colonizations, extinctions, and local demography 


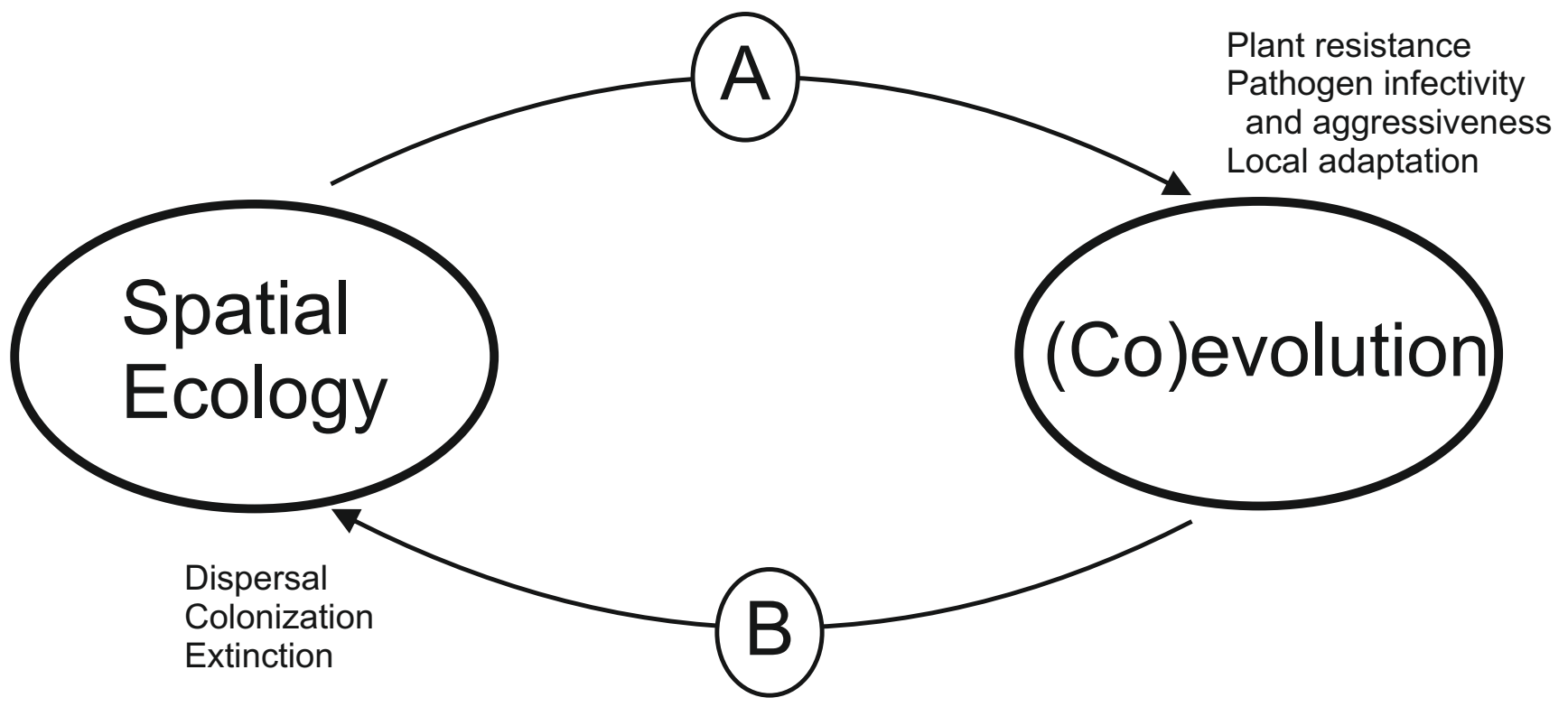

